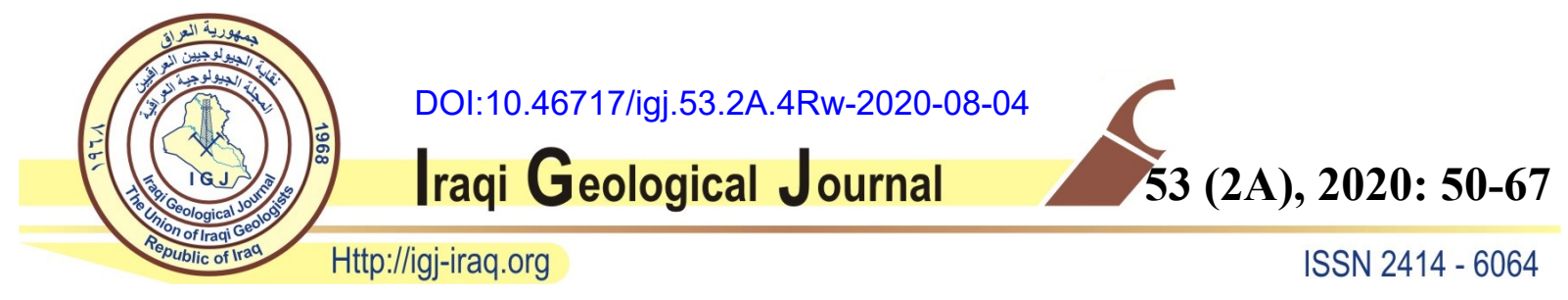

\title{
WELL LOGS DATA PREDICTION OF THE NAHR UMR AND MISHRIF FORMATIONS IN THE WELL NOOR-10, SOUTHERN IRAQ
}

\author{
${ }^{\mathbf{1}}$ Abbas K.A. Mohammed ${ }^{*}$, ${ }^{\mathbf{1} J a w a d ~ K . ~ R a d h i ~ a n d ~}{ }^{\mathbf{1} S a d a} \mathrm{Z}$. Ali \\ ${ }^{1}$ Geology Department, Field Division, Ministry of Oil, Missan Oil Company, Misan, Iraq \\ *E-mail: goldengeo.87@gmail.com \\ Received: 22 March 2020; accepted: 18 May 2020
}

\begin{abstract}
Well logs data are the most widely used data to evaluate subsurface rocks, their petrophysical properties include porosity, permeability and fluid saturation. They are essential for the hydrocarbon reserves estimations and perforation zones determination for production purposes and fields development. Well logging operations of the targeted reservoirs could not be done in NO-10 Well, Noor Oilfield, Southern Iraq due to some problems related to the well condition. The gamma-ray and sonic logs were the only recorded logs, while neutron, density and deep resistivity logs are missed. The missing neutron, density and deep resistivity logs of the Early Cretaceous Nahr Umr Sandstone and the Late Cretaceous Mishrif formations of the well NO-10 were produced and compared together using the Artificial Neural Network ANN in Petrel software. The results show that the total correlation of the ANN Nahr Umr model for the neutron, density and deep resistivity logs are $0.81,0.49$ and 0.51 respectively. Interestingly, the ANN Mishrif Formation model recorded 0.88, 0.92 and 0.81 for neutron, density and resistivity logs respectively. The results show excellent relationships between the original and the predicted logs in the Mishrif model, unlike the Nahr Umr model expect in ANN of the neutron log. It was expected that the total relationships are low in Nahr Umr due to the lithology variation that includes interbedded consolidated and unconsolidated sandstone interbedded with the shale. It is also observed that the gamma log shows low values and the caliper logs is smoothed in the Mishrif. In contrast, the Nahr Umr sandstone logs show that many washouts have occurred. Therefore, logs' responses highly possible to be affected in the Nahr Umr Formation which leads to a decreasing in the of defficient derminations.
\end{abstract} Keywords: Artificial Neural Network; Well logs prediction; Noor Oilfield; Nahr Umr and Mishrif formations 


\section{INTRODUCTION}

The Noor-10 well was drilled in the Noor Oilfield to produce hydrocarbons from the Nahr Umr sandstone. The drilling operations commenced, and the first two hole-sections $\left(17^{1 / 2}\right.$ " and $12^{1 / 4}$ ") were completed and cased at the depth of $2333 \mathrm{~m}$. During drilling the third hole-section $\left(8^{3 / 8}\right.$

" section) that contains the reservoirs layers that include the Mishrif and Nahr Umr formations, then a problem has occurred, the casing pipes collapsed from the depth of 2318-2333. Several, unfortunately, unsuccessful attempts and operations were made to fix the buckling. After then, another problem has happened, stuck pipes have occurred at a depth of $2900 \mathrm{~m}$. Many attempts to release the drill pipes were unsuccessfully made. Later, it was decided to side-track drilling from the depth of $2344 \mathrm{~m}$ and reached the final depth of the Shu'aiba Formation at the depth of $4139 \mathrm{~m}$. The well logging operations for the full set of tools that supposed to include gammaray, sonic, neutron, density and resistivity logs were not completed due to the well condition. Sonic and GR Logs were the only logs that successfully recorded, while the rest of the logs (neutron, density and resistivity logs) were not completed due to the above-stated problem. Several attempts were made to record the logs in the well with no success. Logs data are the most widely used down-hole data to evaluate subsurface rocks and their physical properties. In addition, they are essential in terms of the electrofacies studies and (Al-Jaberi and Al-Mayyahi, 2018). It is difficult to evaluate the drilled wells by only the use of the gamma-ray and sonic logs without the entire full set of logs. For the oil company's, it is essential to determine the best hydrocarbon zone and to estimate the hydrocarbon accumulations for exploration and development stages. This cannot be done without the calculations of petrophysical properties (including porosity and fluid saturation) and the numerical models. This can be much challenging in siliciclastic sediments such as in Nahr Umr Formation that contains friable and non-friable sandstone interbedded with shale which makes it difficult to determine the reservoir layers. Artificial Neural Network (ANN) technique provides a way to generate the missing well logs data and other significant parameters of subsurface rocks such as permeability, fluid saturation and lithology prediction (Handhel, 2009; Mahdi et al., 2010; Cvetković and Velić, 2013; Salehi et al., 2017). This study aims to generate the missing logs data including neutron, density and resistivity of the Mishrif and Nahr Umr formations in the Noor-10 well to prevent the negligence of the well and link it in the production line. The predicted logs data can, therefore, be used for formations evaluation and to determine the best possible oil zones. 


\section{GEOLOGICAL BACKGROUND}

The Noor oilfield lies in the Mesopotamian basin, southern Iraq, and is located about $17 \mathrm{~km}$ to the northeast of Amara City (Fig. 1a). The field is a gentle anticline with a trend axis of NWSE, with dimensions of about $15 \mathrm{~km} \times 30 \mathrm{~km}$.

(a)

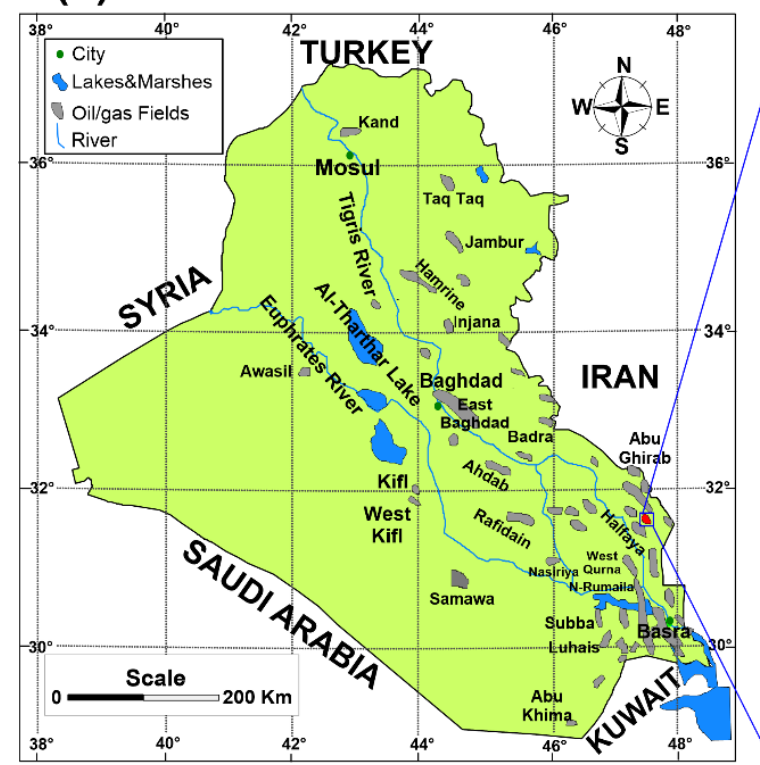

(b)

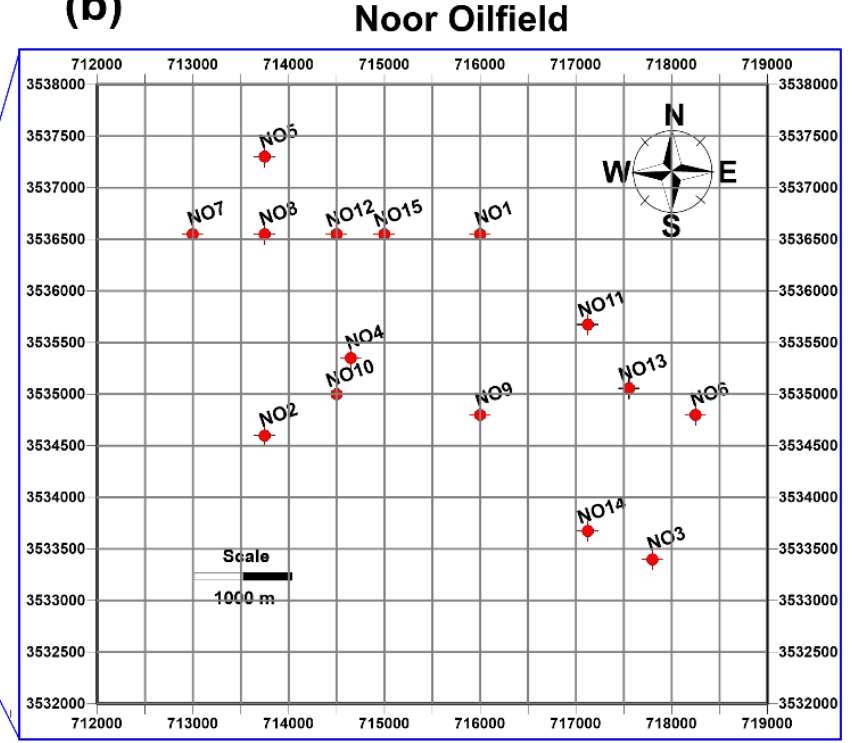

(C)

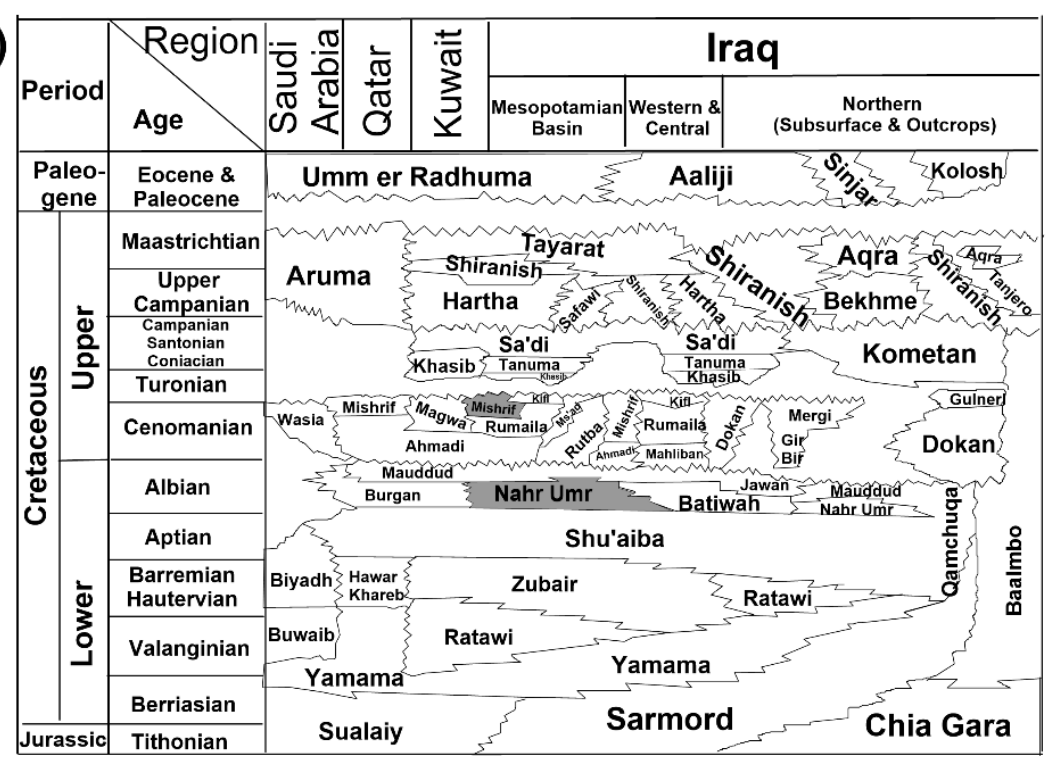

Fig. 1. (a) The Iraqi map shows most oil/gas fields. The red field is an area of interest, Noor Field (from Mohammed, 2018). (b) Noor Oilfield map, Noor-10 the interest of this study. (c) Chronostratigraphic chart of the Cretaceous section in Iraq and some adjacent countries. (Slightly modified and re-draw (Mohammed, 2018 after Sadooni, 2004)), the grey filled refers to the Nahr Umr and Mishrif formations 


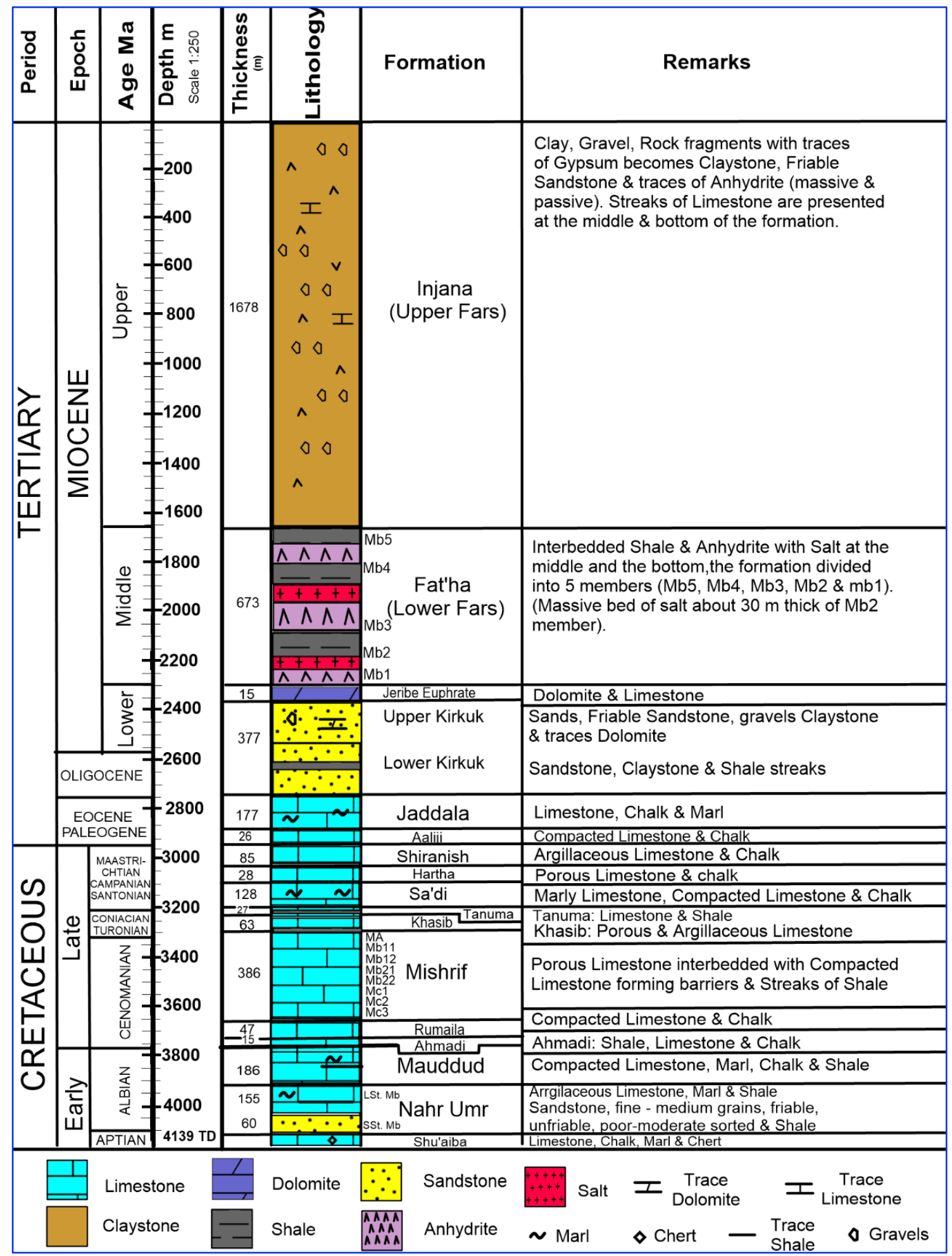

Fig. 2. Stratigraphic column of the Noor-10, the Sandstone Nahr Umr and Mishrif formations are the interest of this study (Adapted from Mohammed, 2018)

The Mishrif is from Late Cretaceous (Late Cenomanian-Early Turonian) and the Nahr Umr if from the Albian, Early Cretaceous (Aqrawi et al., 2010) (Fig. 1c). The Mishrif and Nahr Umr formations are the most producible formations in the central, south and neighbour areas. 
The Mishrif Formation (Cenomanian-Early Turonian age) is the main carbonate reservoirs in middle, southern Iraq and throughout the Middle East (Aqrawi et al., 1998). In southern Iraq, the Mishrif Formation consists of the main rudist-bearing reservoir in many oilfields such as Zubair, West Qurnah, and Nasiryia (Al-Dabbas et al., 2010) and most Missan governorate's Oilfields such as Noor, Amara, Buzurgan, Faqui and Abu Ghirab oilfields. The Mishrif Formation contains up to $40 \%$ of Cretaceous oil reserves in Iraq, and approximately $30 \%$ of the total Iraqi oil reserves (Aqrawi et al., 1998; Aqrawi et al., 2010). The Mishrif gradationally overlies the Rumaila and Kifl formations in most central oilfields. However, in southern Iraq including Missan oilfields, the Mishrif Formation unconformably underlies the Khasib Formation, where the Kifil Formation is absent (Aqrawi 1995). In the Noor oilfield and most Missan oilfields, the Mishrif Formation subdivided into several members (MA, Mb11, Mb12, $\mathrm{Mb} 21, \mathrm{Mb} 22, \mathrm{MC} 1, \mathrm{MC} 2$ and MC3) interbedded with barriers ( $\mathrm{Br} 1, \mathrm{Br}$ 2, $\mathrm{Br}$ 3, $\mathrm{Br} 4, \mathrm{Br}$, $\mathrm{Br}$, $\mathrm{Br} 7$ and $\mathrm{Br} 8$ ) respectively with a total thickness of about $386 \mathrm{~m}$ in the Well Noor-10. The Nahr Umr was first described in its typical section in the Nahr Umr Well 2, where its thickness was about 200m. The Nahr Umr Formation extends widely within Iraq and the Arab Gulf countries including Qatar, Oman, Bahrain, Kuwait and United Arab Emirates. The reservoir quality of Nahr Umr Formation differs horizontally and vertically (Alsharhan, 1991; 1994, Al-Dabbas et al., 2012). Within the Mesopotamian Basin, the Nahr Umr Formation gradationally underlies the Mauddud Formation and un-conformably overlies the Shuaiba Formation. The shale beneath the Mauddud Formation seals the Nahr Umr reservoir. The Nahr Umr Formation is equivalent to the Burgan Formation in the Kuwait region, while the Batiwah Formation is equivalent to the Nahr Umr in some central and northern parts of Iraq (Aqrawi et al., 2010) (Fig. 1c). Final geological reports of the Noor oilfield show that the Nahr Umr Formation is around 200-220m thick (Fig. 2). The Nahr Umr Formation in Missan's region is subdivided into two members, the upper member is limestone and the lower is sandstone which represents a transgression event. The lower unit is about $60 \mathrm{~m}$ thick and contains the main oil-bearing zone; composed of fine-medium grained sandstone interbedded with shale and siltstone. These are interpreted as a fluvial sequence deposited in a shallow marine-deltaic influenced by an aeolian effect (Aqrawi et al., 2010). In the Noor oilfield, the depth average of the Nahr Umr is ranging 3930-3950m, while, the sandstone member exceeds 4050m.

\section{METHODOLOGY}

This study was done by collecting well logs data sets of the wells that penetrated the Nahr Umr Formation and crossed the Mishrif Formation in the Noor oilfield. sixteen wells were drilled in 
the Noor oilfield (Fig. 1b), only five wells have penetrated the Nahr Umr Formation, these are Noor-1, Noor-3, Noor-5, Noor-7, Noor-10, and Noor-13. All wells contain gamma-ray, sonic, neutron, density and resistivity logs except the Noor-10 well which contains only gamma-ray and sonic. The aim is to predict the rest log data of Noor-10 by using of the ANN technique. The Petrel software is used to constrain the ANN models, and the Excel software was used to drawing charts, comparisons, and matching ratios (coefficient of determination $\left(\mathrm{R}^{2}\right)$ ). Neural network technology was first used by McCulloch and Pitts (1943). It is a complex mathematical algorithm that helps to solve many problems that are cannot be fixed by mathematical laws and simulations. ANN is a mathematical method that inspired by the idea of biological neural networks (McCulloch and Pitts, 1943). It consists of simple processing units connected to a complex communication network. It is a mathematical model of a processor largely distributed with parallel networks that use input processing units called neurons to give a single output value to estimate or identify non-linear relationships. The ANN process divides the inserted data into two groups; the first set of data is used for the data training, while the second set is used to test the output data of the ANN network. Accordingly, two sets of performance values are given, one for training and the other for testing. Performance values range from 0 to 1 , where 1 represents a perfect matching or 100\% accuracy. In this study, a neural network model was built to firstly predict the neutron log NPHI by training the inputs data through inserting the gamma-ray and sonic logs as inputs (the existing logs data of Noor-10 well), and selecting of wells was changed each time to obtain the possible highest correlation (high matching and low error), while the neutron log was the output of this neural network model (Fig. 3). After obtaining the highest relationship, the data were tested by matching the output results with already existing data, for example, the original neutron log NPHI of the wells that selected in this neural network model compared to the predicted neutron log. The neutron log of the Noor10 was then generated by the ANN model after obtaining reliable results with a satisfied coefficient of determination. The predicted neutron log was added to the input data (with gamma-ray and sonic logs) for the next step which is density log prediction step and the same steps of prediction of NPHI were applied to the ANN model of prediction of the RHOB as well as the LLD logs (Fig. 3). 


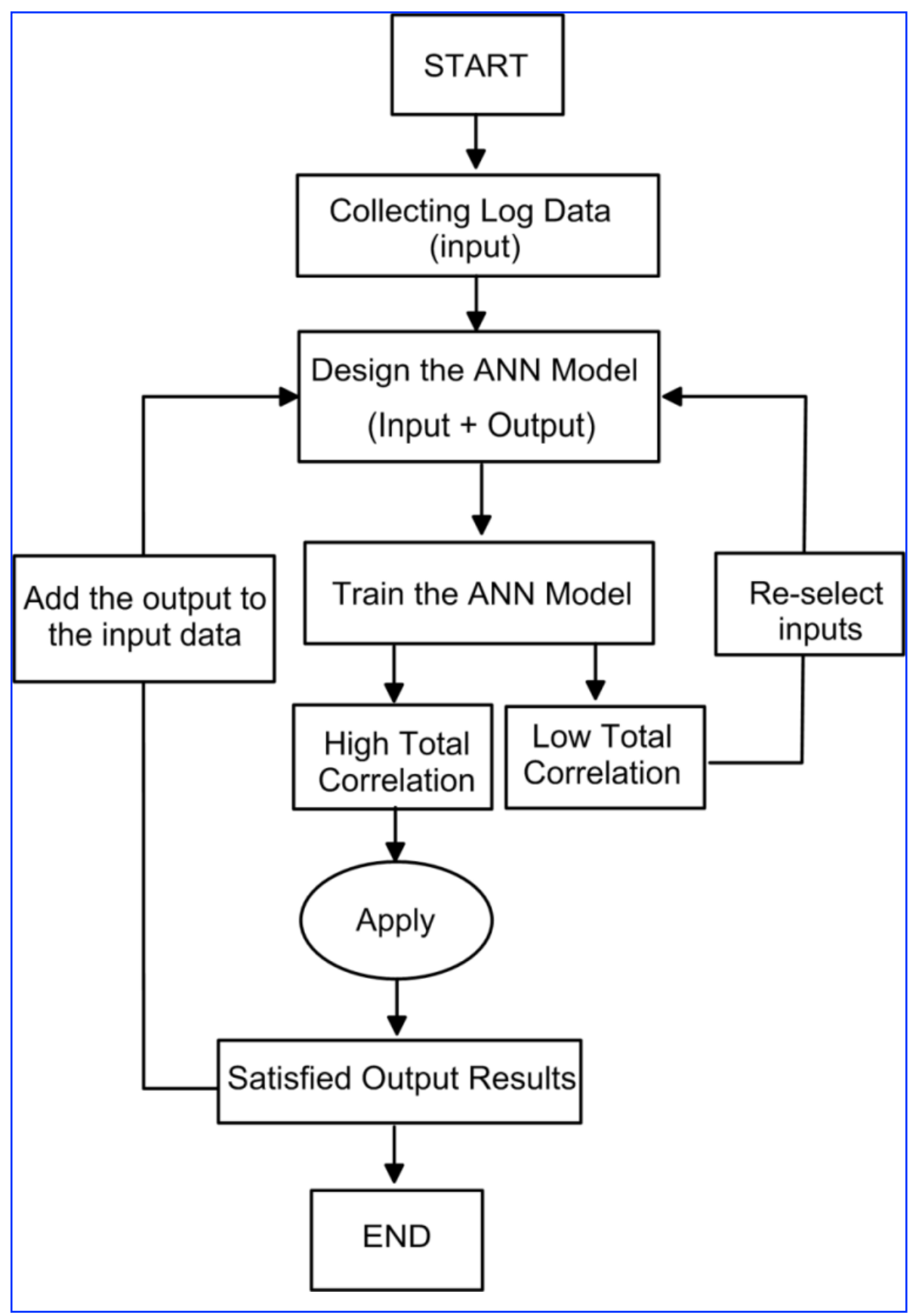

Fig. 3. Basic flow chart of the current study

This study has the advantage to compare the results obtained from the ANN in two different lithologies, the sandstone Nahr Umr and the limestone Mishrif Formation. Therefore, the same chosen wells of the Nahr Umr ANN models were selected for designing the Mishrif ANN models. As mentioned earlier, the input log of NPHI was GR and DT logs, while RHOB inputs logs were predicted NPHI, GR and DT logs, whereas the input logs of LLD were the predicted NPHI, predicted RHOB, GR and DT logs. Table 1 summarises the inputs used in each ANN model. The total correlation of each ANN model represents the possible errors. 
Table 1. A summarising table shows inputs data used in this study for Nahr Umr and Mishrif, and total correlation obtained from each ANN model

\begin{tabular}{|c|c|c|c|c|c|c|}
\hline \multirow{2}{*}{$\begin{array}{c}\text { Predicted } \\
\text { Log }\end{array}$} & \multicolumn{3}{|c|}{ Nahr Umr Sandstone } & \multicolumn{3}{c|}{ Mishrif Limestone } \\
\cline { 2 - 7 } & $\begin{array}{c}\text { Selected } \\
\text { wells No. }\end{array}$ & Selected logs & $\begin{array}{c}\text { Total } \\
\text { correlation }\end{array}$ & $\begin{array}{c}\text { Selected } \\
\text { wells No. }\end{array}$ & Selected logs & $\begin{array}{c}\text { Total } \\
\text { correlation }\end{array}$ \\
\hline NPHI & $\begin{array}{c}1,7 \text { and } \\
13\end{array}$ & GR and DT & 0.81 & $\begin{array}{c}1,7 \text { and } \\
13\end{array}$ & GR and DT & 0.88 \\
& 1 and 7 & $\begin{array}{c}\text { GR, DT and } \\
\text { predicted } \\
\text { NPHI }\end{array}$ & 0.49 & 1 and 7 & $\begin{array}{c}\text { GR, DT and } \\
\text { predicted } \\
\text { NPHI }\end{array}$ & 0.92 \\
\hline LLD & 7 and 13 & $\begin{array}{c}\text { GR, DT, } \\
\text { predicted } \\
\text { NPHI and } \\
\text { predicted } \\
\text { RHOB }\end{array}$ & 0.51 & 7 and 13 & $\begin{array}{c}\text { GR, DT, } \\
\text { predicted } \\
\text { NPHI and } \\
\text { predicted } \\
\text { RHOB }\end{array}$ & 0.81 \\
\hline
\end{tabular}

\section{RESULTS}

\section{Nahr Umr ANN Model}

The total correlation of the ANN model that built to predict the NPHI log in the main sandstone member of Nahr Umr Formation using Noor-1, Noo1-7 and Noor-13 as the selected wells in the model reaches 0.81 , indicating to a possible low degree of error (Table 1). To assess the results and to check their validation, the predicted NPHI log plotted against the original NPHI $\log$ of the wells that selected in this ANN model (Noor-1, Noo1-7 and Noor-13) (Fig. 4a, b and c). Where, the coefficient of determination $\left(\mathrm{R}^{2}\right)$ reaches $0.778,0.719$ and 0.707 in Noor-13, Noor-1 and Noor-7 respectively (Fig. 4a, b and c). To see how the predicted NPHI match the original ones, the original NPHI plotted with the predicted NPHI with depth for Noor-1, Noo17 and Noor-13 wells (Fig. 5a, b and c). Similarly, and after adding the NPHI log with the input logs data (as mentioned the methodology section), the RHOB predicted logs plotted against the original (actual) logs for the Noor-7 and Noor-1 involved wells (Fig. 4d and e). The predicted RHOB plotted with the original RHOB log against depth to observe the matching between them (Fig. 6a and b). This also applied to the prediction of the LLD log, where the predicted LLD plotted against the original LLD logs of the Noor-7 and Noor-13 wells that selected into the ANN model of predicting the LLD $\log$ (Fig. 4f and g), and the predicted LLD logs also plotted with the original logs versus depth (Fig. $6 \mathrm{c}$ and d). 

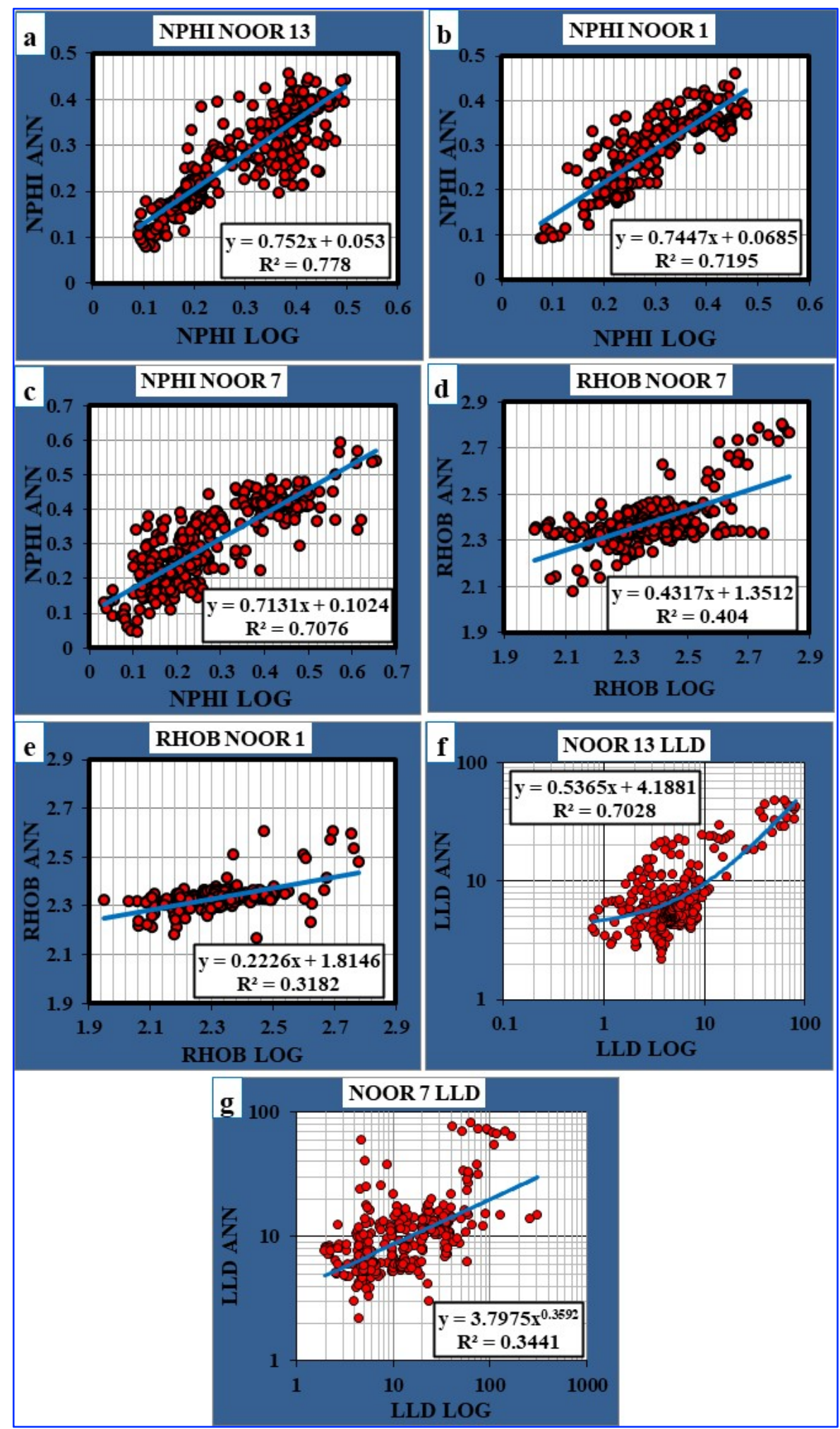

Fig. 4. a, b, c) Cross plots of the original NPHI log against the predicted log by the ANN model for Nahr Umr Formation. $d$ and e) Cross plots of the predicted RHOB versus the original RHOB logs of the Noor-7 and Noor-1 respectively. $f$ and g) Cross plots the predicted LLD against the original LLD logs of the Noor-13 and Noor-7 wells respectively. The $\mathrm{Y}$-axis represents the predicted logs from the ANN models for each NPHI, RHOB and LLD, the cross plots show the correlation of determination $\left(R^{2}\right)$ 

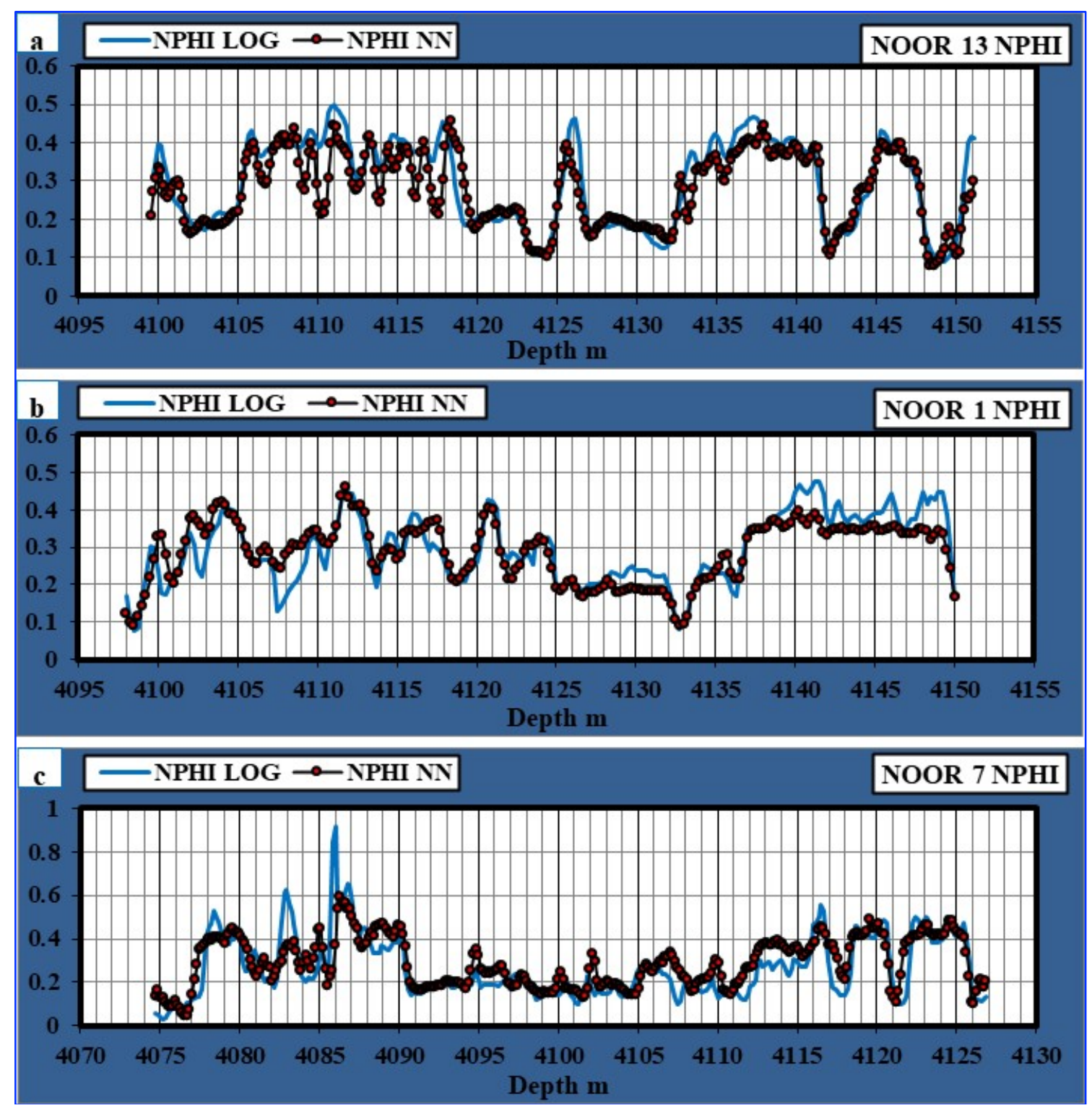

Fig. 5. a, b and c) plots of the predicted NPHI log for the Nahr Umr ANN models and the originals NPHI logs against depth for each Noor-13, Noor-1 and Noor-7 respectively. NPHI log is the original neutron log, whereas the NPHI NN is the predicted neutron log

\section{Mishrif ANN Model}

The total correlation of the Mishrif model of each log shows higher values than in the Nahr Umr ANN model (Table 1), where they recorded 0.88, 0.92 and 0.81 in NPHI, RHOB and LLD logs respectively. Overall, the results of cross plotting the predicted NPHI, RHOB and LLD logs in the Mishrif Formation ANN model, the coefficient of determination $\left(\mathrm{R}^{2}\right)$ recorded higher values than in the Nahr Umr ANN model (Figs. 4 and 7). To assess the matching between the predicted log and the original logs, the predicted and the original NPHI, RHOB and LLD logs plotted versus depth (Figs. 8 and 9). 

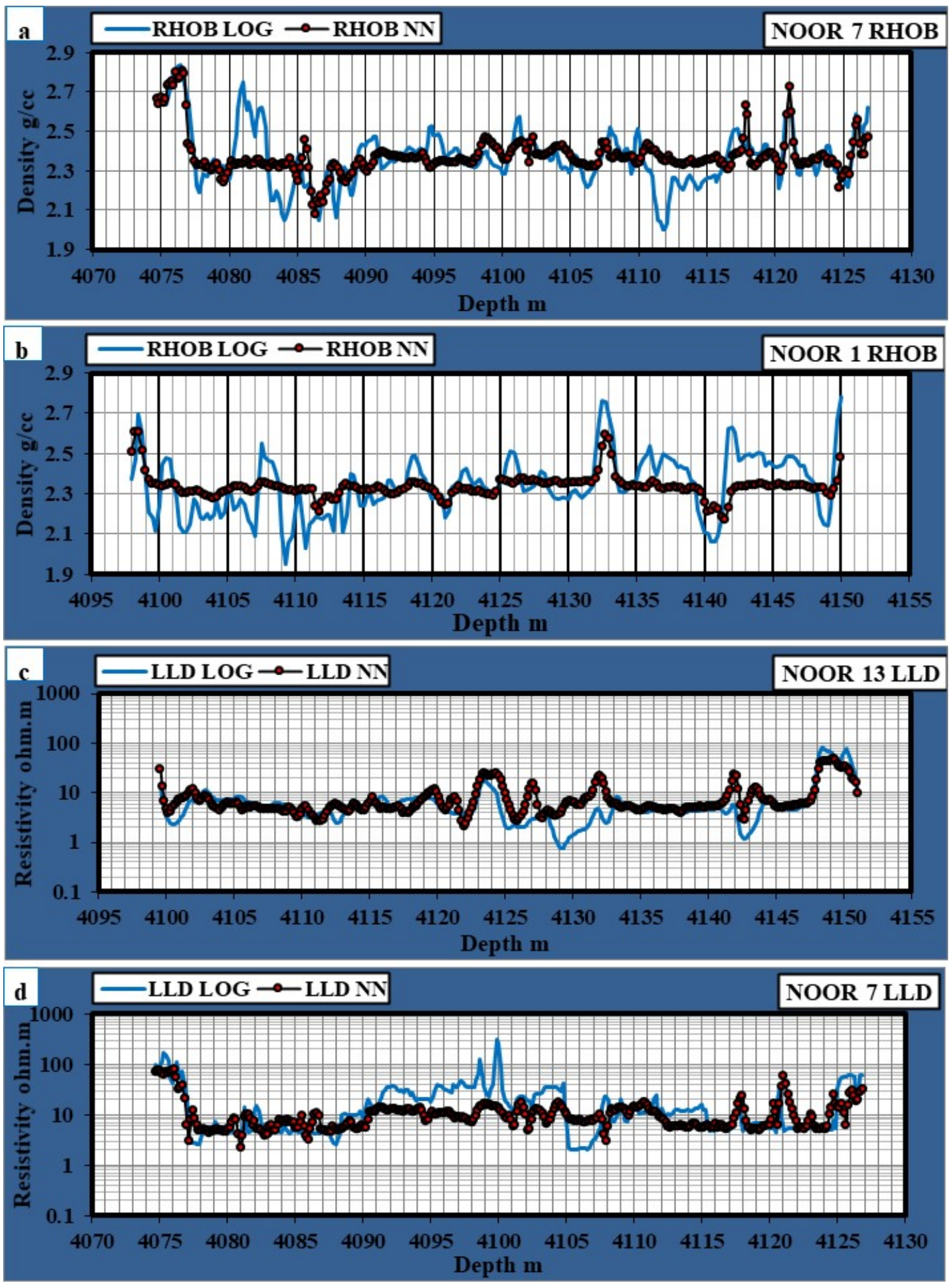

Fig. 6. a and b) Plots of the predicted RHOB log from the ANN models and the originals RHOB logs against depth for each Noor-7 and Noor-1 respectively. $c$ and d) Plots of the predicted LLD log from the ANN models and the originals LLD logs versus depth for each Noor-13 and Noor-7, respectively 


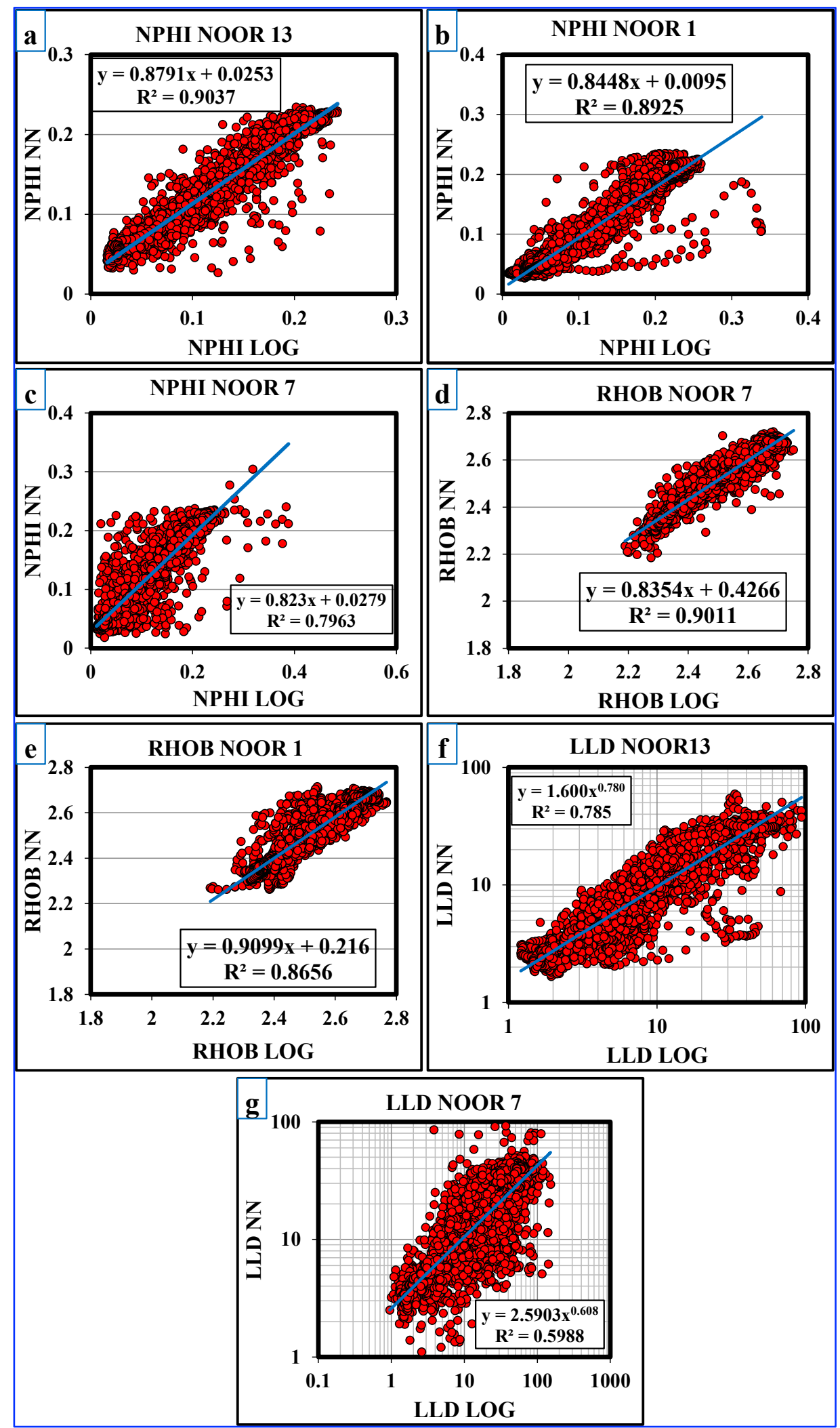

Fig. 7. a, b, c) Cross plots of the original NPHI log against the predicted log by the ANN model for Mishrif Formation. $d$ and e) Cross plots of the predicted RHOB versus the original RHOB logs of the Noor-7 and Noor-1 respectively. $f$ and g) Cross plots the predicted LLD against the original LLD logs of the Noor-13 and Noor-7 wells respectively. The $\mathrm{Y}$-axis represents the predicted logs from the ANN models for each NPHI, RHOB and LLD, the cross plots show the correlation of determination $\left(R^{2}\right)$ 

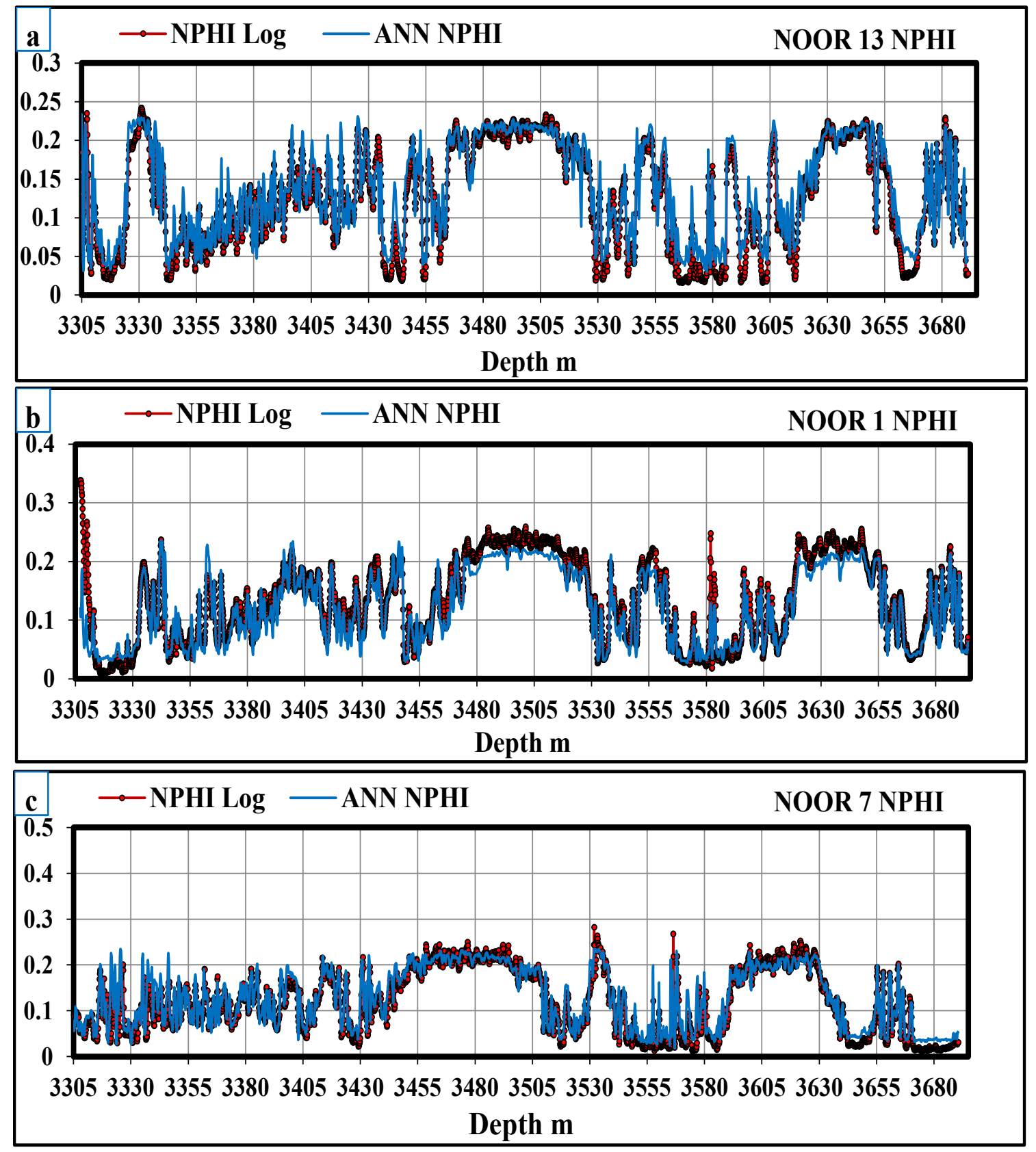

Fig. 8. a, $b$ and c) plots of the predicted NPHI log for the Mishrif ANN models and the originals NPHI logs against depth for each Noor-13, Noor-1 and Noor-7 respectively. NPHI log is the original neutron log, whereas the ANN NPHI is the predicted neutron log 

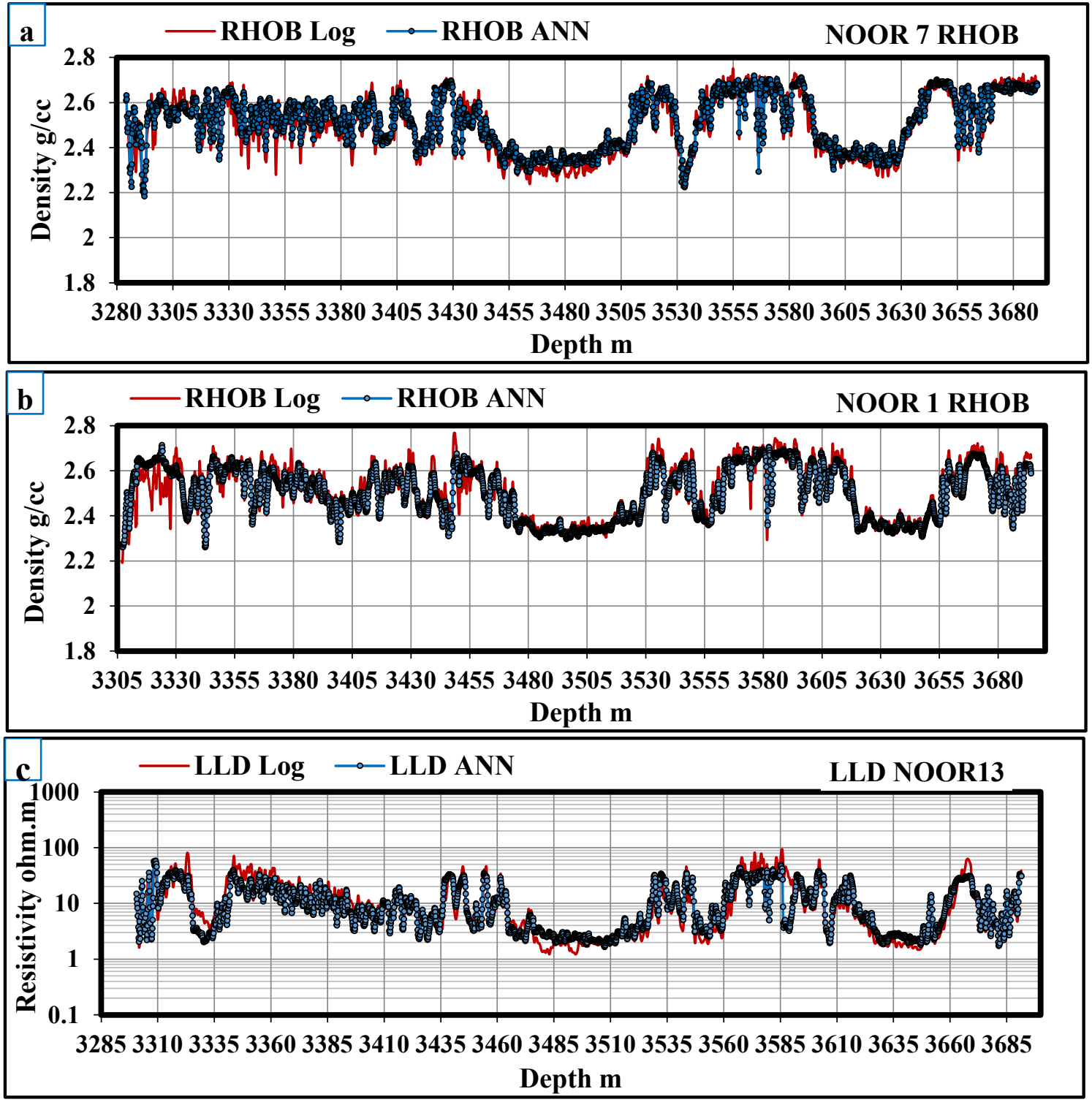

Fig. 9. a and b) Plots of the predicted RHOB log for the Mishrif ANN models and the originals RHOB logs against depth for each Noor-7 and Noor-1 respectively. $c$ and d) Plots of the predicted LLD log from the ANN models and the originals LLD logs versus depth for each Noor-13 and Noor-7 respectively

\section{DISCUSSION}

ANN technique provides a way to generate missing well logs data and other significant parameters of subsurface rocks such as permeability and lithology prediction (Handhel, 2009; Mahdi et al., 2010; Cvetković and Velić, 2013; Salehi et al., 2017). It is obvious that the ANN model of the Mishrif Formation has higher correlations and matching results than the Nahr Umr Formation ANN model (Table 1, Fig. 4 and Fig. 7). It was stated earlier that the Nahr Umr Formation consists of consolidated and unconsolidated sandstone interbedded with shale the layers, the caliper log (Fig. 10a and b) shows that the Nahr Umr borehole size varies referring 
to many washouts that have occurred (particularly, in front of the shale zones), while the caliper $\log$ of the Mishrif Formation shows tighten borehole wall with no washout records. This might affect the Nahr Umr Formation logs responds, particularly, in the RHOB and LLD models, and this highly possible to be the reason why the Nahr Umr ANN model recorded low correlations and matching values. However, the neutron log ANN models of Nahr Umr Formation show good and reasonable matching (Fig. 4a and Fig. 5a).

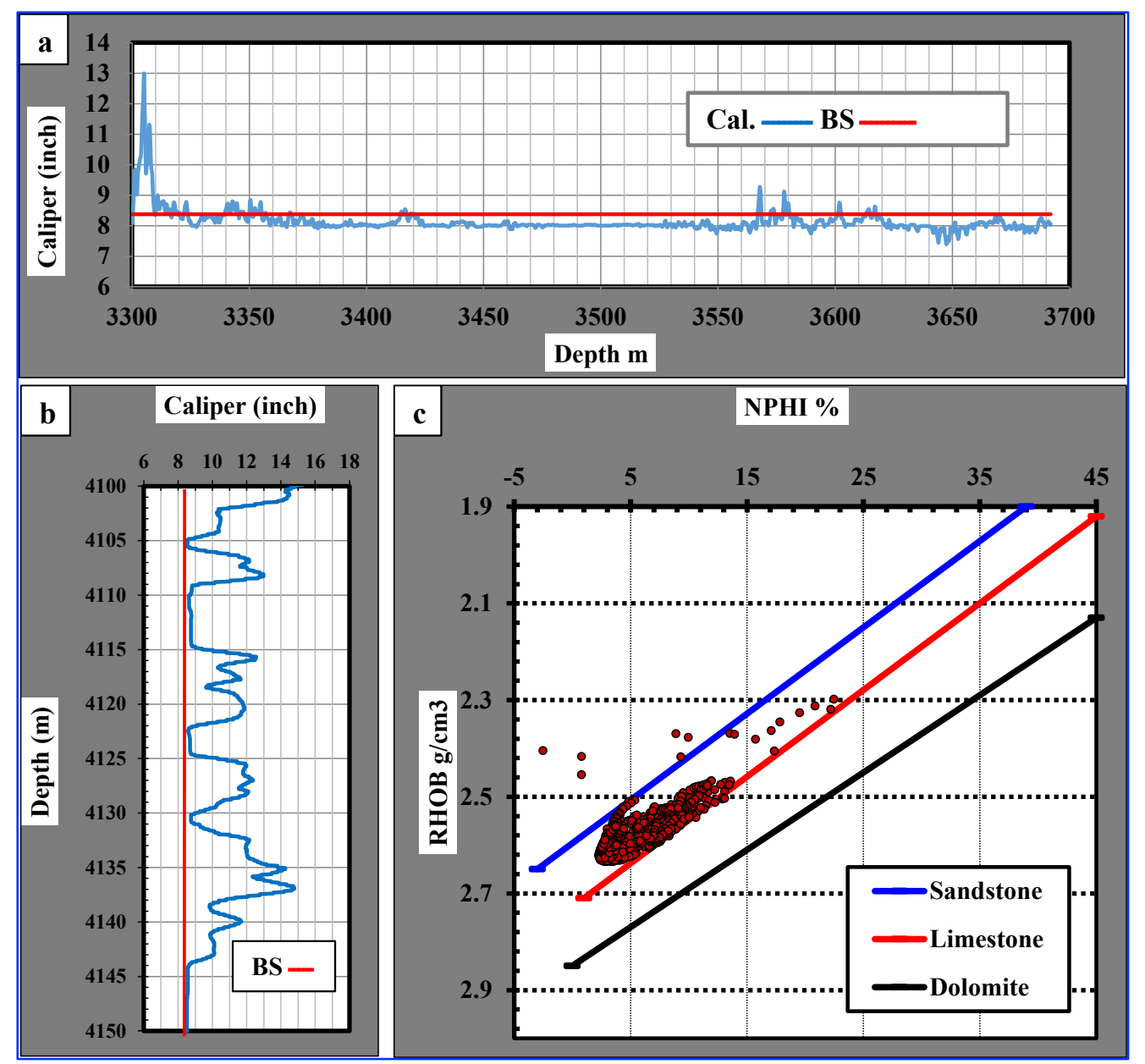

Fig. 10. a) Caliper of the Mishrif Formation (top is 3302m and bottom 3690m), Noor-13. b) Caliper log of the Nahr Umr Formation, Noor-13. c) Density-neutron cross plot, both, RHOB and NPHI are generated from the ANN models

(Baker Hughes interpretation charts)

It is important to show that the validity of the results, the Mishrif Formation predicted logs show high coefficient correlations with low error possibilities. Another evidence that has to be shown and which supports the results accuracy is presented in Fig. 10c, the figure shows a cross plot between RHOB and NPHI logs data that produced from the ANN models. Importantly, all data points are fallen on the limestone line, where it is known that the Mishrif Formation consists of limestone. From all the above, it can be stated that the predicted neutron log from 
the Nahr Umr ANN model can be used to evaluate the porosity and fluid saturation (Archie's equations) of the formation and to evaluate the formation in terms its oil zones (Fig. 11). However, RHOB and LLD logs have to be carefully treated. In contrast, the predicted logs of the Mishrif Formation (Fig. 12) are hence capable to be confidently used to evaluate the formation in terms of porosity, fluid saturation and modelling other petrophysical properties with high accuracy. Therefore, it is now possible to determine the oil zone in both formations.

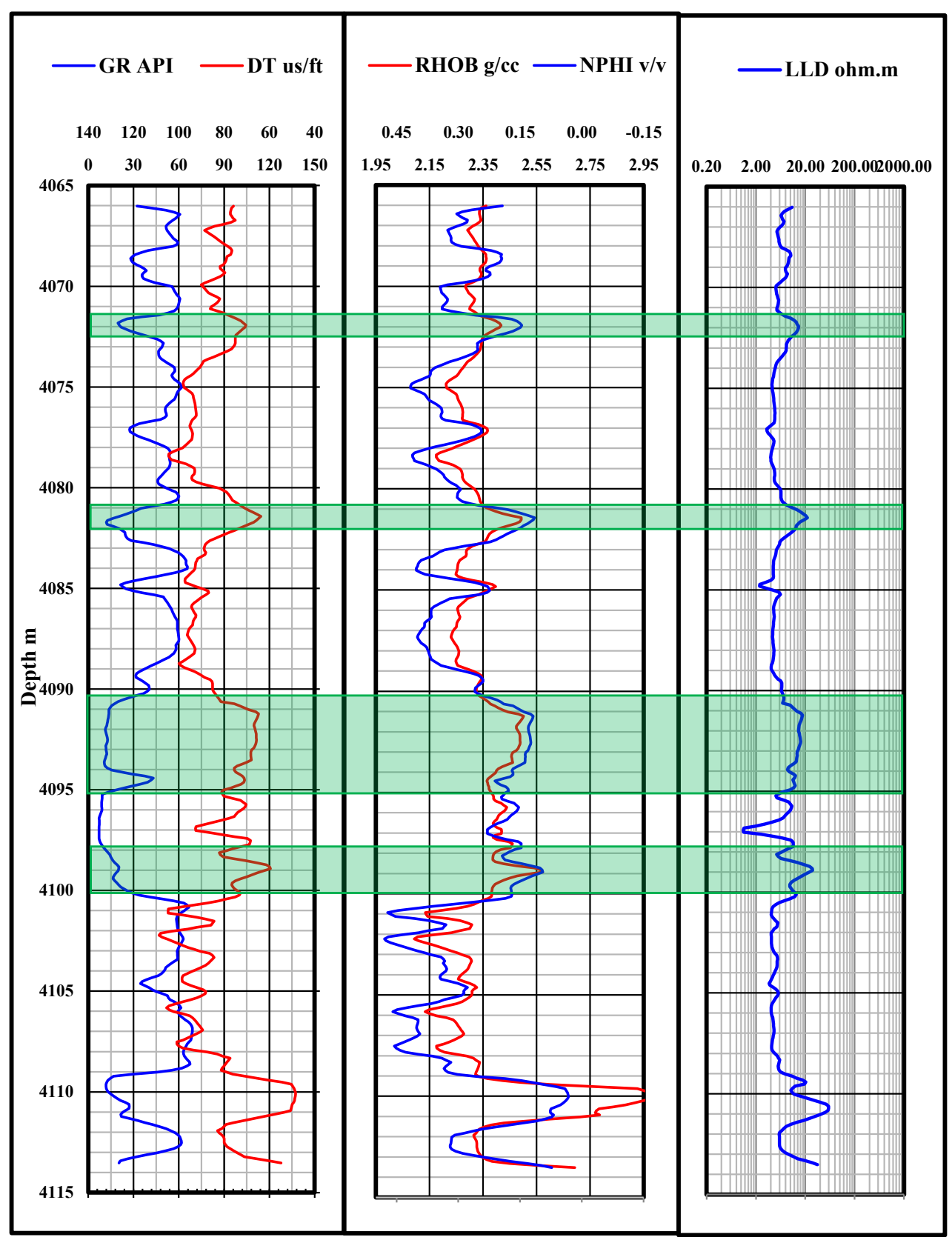

Fig. 11. A plot of the well logs data of Noor-10, Nahr Umr Formation, sandstone member, from $4066 \mathrm{~m}$ to $4114 \mathrm{~m}$, it includes the pre-existing gamma-ray, sonic logs, the predicted neutron, density and deep resistivity logs. It shows the possible oil zones as indicated with the light green color rectangles, the interval from $4090-4095 \mathrm{~m}$ is seemingly the best possible oil-bearing zone 


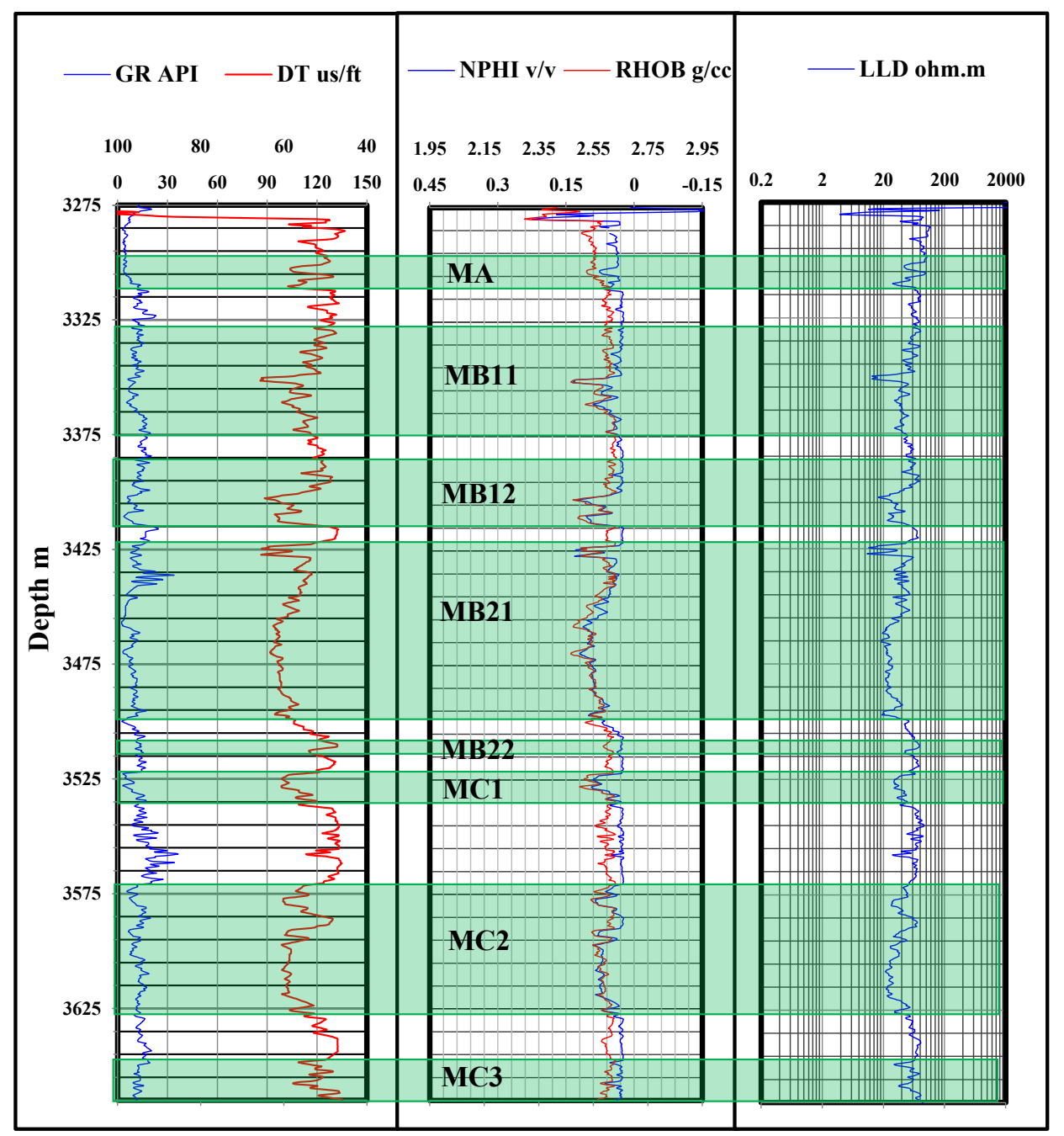

Fig. 12. A plot of the well logs data of Noor-10, Mishrif Formation starting from 3278m to $3665 \mathrm{~m}$, includes the pre-existing gamma ram, sonic logs, the predicted neutron, density and deep resistivity logs, show members of the Mishrif Formation; MA, MB11, and MB12 which are the main oil-bearing zones, with less oil show in MB21 and in MB22, MC1, MC2 and MC3, all zones are separated by barriers

\section{CONCLUSIONS}

This study aims to generate the missing well logs in well Noor-10. The neutron porosity, density and deep resistivity logs (NPHI, RHOB and LLD) of the well Noor-10 were generated by using the ANN technique for the Nahr Umr and Mishrif formations. It is, therefore, possible to evaluate the both formations and assess the porosity and the fluid saturation based on the preexisting and the generated well logs. Using the RHOB and LLD logs generated from the ANN has to be carefully treated. However, the NPHI logs can be used to evaluate porosity and considered during the fluid saturation calculations. The borehole condition and caves have negatively affected the well logs responses of the sandstone member in the Nahr Umr Formation. The Mishrif Formation predicted logs data can accurately be used to evaluate the 
formation and assess the hydrocarbon accumulations. Hence, well logging operations can then be reduced and cancelled as the ANN technique can be used to reimburse and generate well logs data, particularly in clean, smoothed and tight formations.

\section{ABBREVIATIONS}

ANN= Artificial Neural Network; GR= Gamma-Ray Log; DT= Sonic Log; NPHI= Neutron Log; RHOB= Density Log; LLD= Deep Resistivity Log.

\section{ACKNOWLEDGEMENTS}

The authors would express their appreciation to Missan Oil Company for their permission to publish this work. The authors are very grateful to the editor in chief Prof. Dr. Salih M. Awadh, the secretary of Journal Mr. Samir R. Hijab. and head of the technical editors Dr. Heba S. AlMimar for their great efforts and valuable comments.

\section{REFERENCES}

Al-Dabbas, M., Al-Jassim, J., and Al-Jumaily, S., 2010. Depositional environments and porosity distribution in regressive limestone reservoirs of the Mishrif Formation, Southern Iraq. Arabian Journal of Geosciences, 3:67-78. DOI 10.1007/s12517-009-0057-x.

Al-Dabbas, M. A., Al-Jassim, J. A., and Qaradaghi, A. I., 2012. Siliciclastic deposit of the Nahr Umr Formation, sedimentological and depositional environment studies, central and southern Iraq. Arabian Journal of Geosciences, 6:4771-4783. https://doi.org/10.1007/s12517-012-0747-7.

Al-Jaberi, M. H., and Al-Mayyahi, H. K., 2018. Wireline logging response and true core analysis of the upper shale member of Zubair Formation, Rumaila oilfield, Southern Iraq. Iraqi Geological Journal, 51:28-40.

Alsharhan, A. S., 1991. Sedimentological interpretation of the Albian Nahr Umr Formation in the United Arab Emirates. Sedimentary Geology, 73:317-327. doi: 10.1016/0037-0738(91)90091-Q.

Alsharhan, A.S., 1994. Albian Clastics in the Western Arabian Gulf Region: a Sedimentological and PetroleumGeological Interpretation. Journal of Petroleum Geology, 17:279-300. doi: 10.1111/j.17475457.1994.tb00135.x.

Aqrawi, A. A. M., 1995. Brackish-water and evaporitic Ca-Mg carbonates in the Holocene Lacustrine/deltaic deposits of southern Mesopotamia. Journal of Geology Society of London, 152:259-268.

Aqrawi, A. A. M., Thehni, G. A., Sherwani, G. H., and Kareem, B. M. A., 1998. Mid- Cretaceous rudist bearing carbonates of the Mishrif Formation: an important reservoir sequence in the Mesopotamian Basin, Iraq. Journal of Petroleum Geology, 21(1):57-82.

Aqrawi, A. A., Goff, J. C., Horbury, D., and Sadooni, F., 2010. Petroleum Geology of Iraq. Scientific Press Ltd, Beaconsfield.

Cvetković, M., and Velić, J., 2013. Lithology prediction by artificial neural networks and preparation of input data on Upper Miocene sediments Theories and Applications in Geomathematics, 9-14.

Handhel, A.M., 2009. Prediction of reservoir permeability from wire logs data using artificial neural networks, Iraqi Journal of Science, 50:67-74.

Mahdi, F. M., Di -Giovanni, B. A, Starov, V. M., and Holdich, R., 2010. Permeability Prediction using Artificial Neural Networks from Particle Characterisation Data, Conference: PSA11 Conference and Exhibition, RSC at: Edinburgh, UK. (September). doi: 10.13140/RG.2.1.1565.7049

McCulloch, W. S., and Pitts, W. H., 1943. A logical calculus of the ideas immanent in nervous activity. Bulletin of Mathematical Biophysics, 7:115-133.

Missan Oil Company (M.O.C), Final geological reports, proposals, charts and maps of Noor Field. unpublished.

Mohammed, A. K. A., 2018. Reservoir characteristics of the Khasib Formation in Amara Field, southern Iraq. Iraqi Geological Journal, 51:54-74.

Sadooni, F. N., 2004. Stratigraphy, depositional setting and reservoir characteristics of Turonian-Campanian carbonates in central Iraq. Journal of Petroleum Geology, 27:357-571.

Salehi, M. M., Rahmati, M., Karimnezhad, M., and Omidvar, P., 2017. Estimation of the non-records logs from existing logs using artificial neural networks. Egyptian Journal of Petroleum, 26:957-968. https://doi.org/10.1016/j.ejpe.2016.11.002. 